\title{
Impact of the Polymorphism Near MC4R (rs17782313) on Obesity- and Metabolic-Related Traits in Women Participating in an Aerobic Training Program
}

\author{
by \\ Agata Leońska-Duniec ${ }^{1}$, Zbigniew Jastrzębski², Aleksandra Zarębska², \\ Wojciech Smótka ${ }^{3}$, Paweł Cięszczyk ${ }^{4}$
}

The C/T polymorphism (rs17782313) mapped $188 \mathrm{~kb}$ downstream of the melanocortin-4 receptor gene (MC4R) shows a strong relationship with an increased body mass index (BMI) and the risk of type 2 diabetes. However, the information on polymorphism's potential modifying effect on obesity-and metabolic-related traits achieved through training is still unknown. Therefore, we decided to check if selected body measurements observed in physically active participants would be modulated by the genotype. The genotype distribution was examined in a group of 201 Polish women measured for chosen traits before and after the completion of a 12 week moderate-intensive aerobic training program. A statistically significant relationship between the glucose level and the genotype was identified ( $p=0.046)$. Participants with CC and CT genotypes had a higher glucose level during the entire study period compared with the TT genotype. However, our results did not confirm the relationship between the $C$ allele and an increased BMI or other obesity-related traits. Additionally, we did not observe a near MC4R C/T polymorphism x physical activity interaction. However, our results revealed that majority of obesity-related variables changed significantly during the 12 week training program. The effect sizes $(d)$ of these changes ranged from small to medium $(d=0.11-0.80)$, whereas the largest effect $(d=0.80$; i.e. medium) was reported for the fat mass content $(F M)$. We found a relationship between the near MC4R C/T polymorphism and an increased glucose level, and it is thus a candidate to influence type 2 diabetes. Interestingly, after the 12 week training program, participants with the $C$ (risk) allele with fasting hyperglycemia had a normal glucose level. Although, this change was not statistically significant, it shows an important trend which needs further investigation.

Key words: MC4R, gene x physical activity interaction, exercise, obesity-related traits.

\section{Introduction}

Frequent and regular physical activity has significant benefits for health, including reduction of the risk of cardiovascular diseases, diabetes, cancer, and improvement of mental health (Rankinen and Bouchard, 2008). Additionally, properly selected exercises improve body composition and help control weight. Promoting training programs, particularly in those subjects who are genetically predisposed, is a significant step towards controlling the presently increasing epidemic of obesity (Ahmad et al., 2013; Li et al., 2010). Some studies have confirmed that physical activity is connected with a reduction of up to $40 \%$ in the genetic predisposition to obesity (Ahmad et al., 2013; $\mathrm{Li}$ et al., 2010). Understanding the genetic determinants of

1 - Faculty of Physical Culture and Health Promotion, University of Szczecin, Poland.

2 - Faculty of Tourism and Recreation, Gdansk University of Physical Education and Sport, Poland.

3 - Clinical Department of Laryngology, School of Medicine in Katowice, Medical University of Silesia, Katowice, Poland

4. Faculty of Physical Education, Gdansk University of Physical Education and Sport, Poland. 
reactions occurring in the human body allows detailed and accurate prediction of the consequences of performed exercises. Studies on gene $\mathrm{x}$ physical activity interactions will help identify people who are expected to respond well or poorly to exercise, thus making training programs more efficient (possibility of accurate prediction of the training results) and safer (early prevention of possible overload or other injuries). Nevertheless, so far very few studies have been conducted with the focus on gene $x$ lifestyle interactions (Ahmad et al., 2013; Franks, 2011; Li et al., 2010).

The melanocortin-4 receptor (MC4R) is a well known major regulator of food intake and energy expenditure (Hebebrand et al., 2010). The MC4R is a 332-amino-acid, which belongs to the family of seven trans-membrane G-proteincoupled receptors (GPCR) and is expressed in brain regions involved in regulation of food intake (Gantz et al., 1993; Mountjoy et al., 1994). The MC4R transduces its signal by integrating a satiety signal provided by its agonist $\alpha$ melanocyte-stimulating hormone ( $\alpha$-MSH) and an orexigenic signal provided by its antagonist agouti-related protein (AGRP) (Lu et al., 1994). These ligands are expressed in distinct neuronal populations of the arcuate nucleus of the hypothalamus and are regulated by the adipocyte-secreted hormone, leptin, to control food intake and maintain long-term energy homeostasis (Schwartz et al., 2000). Thus, the MC4R gene has been considered as a genetic marker related to human obesity (Loos et al., 2008).

Genetic variants within the MC4R coding region have been found to be associated with severe and common forms of obesity in humans (Hebebrand et al., 2010). Additionally, polymorphisms outside of the coding region have been associated with a predisposition to polygenic obesity. The non-coding variants of the MC4R probably influence $M C 4 R$ expression, however, a molecular mechanism for the SNPs associations remains unclear (Evans et al., 2014). Metaanalyses of genome-wide association studies (GWAS) conducted in Caucasians revealed that the variant rs17782313 (C/T polymorphism) mapped $188 \mathrm{~kb}$ downstream of the gene (Loos et al., 2008), shows a strong relationship with an elevated body mass index (BMI) (Xi et al., 2012).
In addition to common forms of obesity, rs17782313 has also been associated with earlyonset severe obesity (Meyre et al., 2009; Scherag et al., 2010). These associations have been replicated in multiple populations including children, adolescents and adults (Loos, 2012; Xi et al., 2012).

The minor allele $(C)$ is associated with increased intake of total energy and dietary fat, and as a consequence higher prevalence of common human obesity (Qi et al., 2008). Each copy of the risk allele is associated with an increase in the BMI of $\sim 0.22 \mathrm{~kg} / \mathrm{m}^{2}$ in adults (Loos et al., 2008). Moreover, the $C$ allele was also related with a $14 \%$ increased risk of type 2 diabetes (Qi et al., 2008). Sex has repeatedly been shown to affect the association between rs17782313 and obesity markers, showing a more pronounced effect for female than male mutation carriers (Qi et al., 2008).

Taking into account the rs17782313 polymorphism's role in body weight homeostasis, we decided to examine whether selected traits observed in physically active participants would be modulated by the genotype. To test this hypothesis, we performed a genetic association study that aimed to detect the relationship between the near MC4R $\mathrm{C} / \mathrm{T}$ genetic polymorphism and selected body measurements. Therefore, we studied the genotype distribution in a group of young Polish women measured for chosen body mass and body composition variables, as well as obesity-related metabolic traits before and after a 12 week training program to determine if there was an interaction between the genotype and training. In our opinion, research conducted on amateurs allows for better understanding of the genetic background of posteffort adaptation mechanisms. However, this knowledge can be used for the needs of competitive sports including the modeling of energy management and weight control in professional athletes representing endurance sport disciplines.

\section{Methods}

\section{Ethics Statement}

All the procedures followed in the study were approved by the Ethics Committee of the Regional Medical Chamber in Szczecin (Approval number 09/KB/IV/2011) and were conducted according to the principles of the World Medical 
Association, Declaration of Helsinki and ethical standards in sport and exercise science research. Furthermore, the experimental procedures were conducted in accordance with the set of guiding principles for reporting the results of genetic association studies defined by the Strengthening the Reporting of Genetic Association studies (STREGA) Statement. All participants signed a consent form and were provided with written information concerning the study, providing all pertinent details (purpose, procedures, risks, and benefits of participation).

\section{Participants}

Two hundred and one Polish Caucasian women aged $21 \pm 1$ years (range 19-24) met the inclusion criteria and were selected for the study. None of these individuals had engaged in regular physical activity in the previous 6 months. They had no history of any metabolic or cardiovascular diseases. Participants were nonsmokers and refrained from taking any medications or supplements known to affect the metabolism. Prior to the beginning of the intervention, participants were asked to maintain a balanced diet of approximately $2000 \mathrm{kcal} /$ day.

Physical exercise training protocol

Before the commencement of the training program, HRmax of each participant was evaluated using a continuous graded exercise test on an electronically braked cycle ergometer (Oxycon Pro, Erich JAEGER GmbH, Hoechberg, Germany) according to a previously described protocol (Kostrzewa-Nowak et al., 2015). The training period was preceded by a week-long familiarization stage, when the examined women exercised 3 times a week for 30 minutes, at an intensity of about $50 \%$ of their HRmax. After the week-long familiarization stage, the proper training program started. Training sessions were conducted in a sports hall; a platform was placed in front of the participants on which the instructor presented exercises based on knee bends, lunges, running, skipping and hopping and their combinations creating a choreography set. The individual heart rate (HR) of participants was registered with HR monitors to control the intensity of exercise. The participants were instructed to maintain previously indicated ranges of the $\mathrm{HR}$ or relative value of $\mathrm{HR}_{\max }$ (maximum heart rate, \%). Each training unit consisted of a warm-up (10 min), aerobic exercises which constituted the main part of training (43 min), and stretching and breathing exercises ( 7 min). Aerobic training included two alternating types of exercises - low and high impact. A low impact style comprised movements with at least one foot on the floor at all times, whereas a high impact style included running, hopping, and jumping with a variety of flight phases (de Angelis, 1998). Music of variable rhythm and tempo was incorporated into both styles. A 12week program of low-high impact aerobics was divided as follows: (i) 3 weeks including 9 training units, $60 \mathrm{~min}$ each, at about $50-60 \%$ of HRmax, tempo 135-140 BPM, (ii) 3 weeks comprising 9 training units, $60 \mathrm{~min}$ each, at 60$70 \%$ of HRmax, tempo 140-152 BPM, (iii) 3 weeks including 9 training units, $60 \mathrm{~min}$ each with the intensity of $65-75 \%$ of $\mathrm{HR}_{\max }$, tempo 145-158 BPM, and (iv) 3 weeks consisting of 9 training units, 60 min each with an intensity of $65-80 \%$ of HRmax, tempo 145-160 BPM. All 36 training units were administered and supervised by the same instructor.

\section{Body Composition Measurements}

All participants were measured for selected body mass and body composition variables before and after the completion of the 12 -week training period. Body mass and body composition were assessed with the bioimpedance method using a Tanita TBF 300M electronic scale (Horton Health Initiatives, USA). The examined variables included: total body mass $(\mathrm{kg})$, fat free mass (FFM, $\mathrm{kg}$ ), fat mass percentage $(\mathrm{FM}, \%)$, body mass index $\left(\mathrm{BMI}, \mathrm{kg} \cdot \mathrm{m}^{-2}\right)$, and total body water (TBW, kg).

\section{Biochemical and Hematological Analyses}

Fasting blood samples were obtained in the morning from the elbow vein. Blood samples from each participant were collected in two tubes. For biochemical analyses, a $4.9 \mathrm{~mL}$ S-Monovette tube with ethylenediaminetetraacetic acid (K 3 EDTA; $1.6 \mathrm{mg}$ EDTA/mL blood) and separating gel (SARSTEDT AG \& Co., Nümbrecht, Germany) were used. For complete blood count, a $2.6 \mathrm{~mL} \mathrm{S-}$ Monovette tube with $\mathrm{K} 3$ EDTA $(1.6 \mathrm{mg}$ EDTA/mL blood) (SARSTEDT AG \& Co., Nümbrecht, Germany) was used. Blood samples for biochemical analyses were centrifuged $300 \times \mathrm{g}$ for 15 minutes at room temperature in order to receive blood plasma. Biochemical and hematological analyses were performed before the 
beginning of the training program and repeated after its completion. The analyses were performed immediately after the blood collection. Complete blood count, including white blood cells (WBC), red blood cells (RBC), haemoglobin (HGB), haematocrit (HTC), mean corpuscular volume $(\mathrm{MCV})$, mean corpuscular haemoglobin $(\mathrm{MCH})$, mean corpuscular haemoglobin concentration (MCHC), and total platelet level (PLT) was obtained using a Sysmex K-4500 Haematology Analyzer (TOA SYSMEX, Kobe, Japan). All biochemical analyses were conducted using a Random Access Automatic Biochemical Analyzer for Clinical Chemistry and Turbidimetry A15 (BIO- SYSTEMS S.A., Barcelona, Spain). Blood plasma was used to determine the lipid profile: triglycerides ( $\mathrm{Tg}$ ), cholesterol (Chol), high-density lipoprotein (HDL) and low-density lipoprotein (LDL) concentrations. Plasma $\mathrm{Tg}$ and Chol concentrations were determined by a diagnostic colorimetric enzymatic method according to the manufacturer's protocol (BioMaxima S.A., Lublin, Poland). Manufacturer's declared intra-assay coefficients of variation $(\mathrm{CV})$ of the method were $<$ $2.5 \%$ and $<1.5 \%$ for the $\mathrm{Tg}$ and Chol determinations, respectively. HDL plasma concentration was determined using a human anti-B-lipoprotein antibody and colorimetric enzymatic method according to the manufacturer's protocol (BioMaxima S.A., Lublin, Poland). The manufacturer's declared intra-assay $\mathrm{CV}$ of the method was $<1.5 \%$. Plasma concentrations of LDL were assessed using a direct method according to the manufacturer's protocol (PZ Cormay S.A., Lomianki, Poland). The manufacturer's declared intra-assay $\mathrm{CV}$ of the method was $4.97 \%$. All procedures were verified using multiparameteric control serum (BIOLABO S.A.S, Maizy, France), as well as control serum of normal level (BioNormL) and high level (BioPathL) lipid profiles (BioMaxima S.A., Lublin, Poland).

\section{Genetic Analyses}

The buccal cells donated by the subjects were collected in Resuspension Solution (GenElute Mammalian Genomic DNA Miniprep Kit, Sigma, Germany) using sterile foam-tipped applicators (Puritan, USA). DNA was extracted from the buccal cells using a GenElute Mammalian Genomic DNA Miniprep Kit (Sigma, Germany) according to the manufacturer's protocol. All samples were genotyped in duplicate using an allelic discrimination assay on a StepOne Real-Time Polymerase Chain Reaction (RT-PCR) instrument (Applied Biosystems, USA).

\section{Statistical Analyses}

Allele frequencies were determined by gene counting. A chi-square test was used to examine the Hardy-Weinberg equilibrium. To determine the influence of the near MC4R C/T polymorphism on training response, the $2 \times 2$ mixed-design ANOVA was used. The Kolmogorov-Smirnov test was applied to check for data normality. The level of statistical significance was set at $p<0.05$. Additionally, to determine effect sizes (d), difference in means was divided by standard deviation of the difference between means. For interpretation of the meaningfulness of the findings, effect sizes according to Cohen's d were calculated and interpreted as follows: 0.2 to $<0.6$, small; 0.6 to $<1.2$, medium; 1.2 to $<2.0$, large; 2.0 to $<4.0$, very large; and $\geq 4.0$, extreme large (Hopkins et al., 2009).

\section{Results}

The near MC4R genotypes were in HardyWeinberg equilibrium. In order to examine the hypothesis that the near MC4R C/T polymorphism modulated training response, we conducted a mixed $2 \times 2$ ANOVA with one between-subject factor (the near MC4R genotype: $\mathrm{TT}$ vs $\mathrm{CC}+\mathrm{CT}$ ) and one within-subject factor (time: before training vs after training) (Table 1). Except for TBW, Chol, and LDL, all variables changed significantly during training ( $\mathrm{d}$ ranged from small to medium, 0.11 to 0.80 ), however, none of the variables changed significantly across the near MC4R genotypes (genotype $\mathrm{x}$ training interaction). The main effect of genotype was found for glucose, $p=0.046$ (Table 1). We did not identify a relationship between the genotype and body height $(p=0.726)$.

insert Table 1 here

\section{Discussion}

Recently, in two GWAS, the common polymorphism rs17782313 near MC4R gene was shown to be associated with increased obesity risk and type 2 diabetes (Loos et al., 2008; Thorleifsson et al., 2009). However, it still remained to be established whether the described relationship of 
this polymorphism with a higher BMI is related to the MC4R's role in obesity, or whether it has an independent role in regulation of body weight. Of interest is that this SNP is not only associated with a higher BMI, but also with increased height, which is consistent with the phenotype of individuals with mutations within the MC4R coding region (Loos et al., 2012). We hypothesized that rs17782313 may be a marker of the casual genetic variant in a regulatory region of the $M C 4 R$. This is consistent with observations that regulatory regions can be several hundred kilobases away from the affected gene (Chambers et al., 2008).

\section{Table 1}

The near MC4R genotypes and response to training (two-way mixed ANOVA)

\begin{tabular}{|c|c|c|c|c|c|c|c|}
\hline \multirow{2}{*}{ Variable } & \multicolumn{2}{|c|}{$\mathrm{CC}+\mathrm{CT}(\mathrm{n}=78)$} & \multicolumn{2}{|c|}{$\mathrm{TT}(\mathrm{n}=123)$} & \multirow{2}{*}{ - Genotype } & \multirow{2}{*}{ Training } & \multirow{2}{*}{$\begin{array}{c}\text { Genotyp } \\
\text { ex } \\
\text { Training }\end{array}$} \\
\hline & $\begin{array}{l}\text { Before } \\
\text { training }\end{array}$ & $\begin{array}{c}\text { After } \\
\text { training }\end{array}$ & $\begin{array}{l}\text { Before } \\
\text { training }\end{array}$ & After training & & & \\
\hline \multirow[t]{2}{*}{ Body mass (kg) } & $60.6 \pm 8.3$ & $59.6 \pm 8.0$ & $60.8 \pm 7.4$ & $60.1 \pm 7.4$ & $p=0.726$ & $p<0.001^{*}$ & $p=0.219$ \\
\hline & \multicolumn{2}{|c|}{$d=-0.65$} & \multicolumn{2}{|c|}{$d=-0.41$} & & & \\
\hline \multirow[t]{2}{*}{$\mathrm{BMI}\left(\mathrm{kg} \cdot \mathrm{m}^{-2}\right)$} & $21.5 \pm 2.3$ & $21.2 \pm 2.3$ & $21.7 \pm 2.4$ & $21.5 \pm 2.4$ & $p=0.436$ & $p<0.001^{*}$ & $p=0.246$ \\
\hline & \multicolumn{2}{|c|}{$d=-0.66$} & \multicolumn{2}{|c|}{$d=-0.37$} & & & \\
\hline \multirow[t]{2}{*}{$\mathrm{FM}(\%)$} & $23.9 \pm 6.0$ & $22.2 \pm 6.3$ & $24.0 \pm 5.2$ & $22.7 \pm 5.3$ & $p=0.710$ & $p<0.001^{*}$ & $p=0.246$ \\
\hline & \multicolumn{2}{|c|}{$\mathrm{d}=-0.80$} & \multicolumn{2}{|c|}{$\mathrm{d}=-0.53$} & & & \\
\hline \multirow[t]{2}{*}{ FFM (kg) } & $45.6 \pm 3.5$ & $46.1 \pm 3.4$ & $45.8 \pm 3.1$ & $46.2 \pm 3.2$ & $p=0.718$ & $p<0.001^{*}$ & $p=0.439$ \\
\hline & \multicolumn{2}{|c|}{$\mathrm{d}=0.48$} & \multicolumn{2}{|c|}{$\mathrm{d}=0.27$} & & & \\
\hline \multirow[t]{2}{*}{ TBW (kg) } & $33.4 \pm 2.6$ & $33.3 \pm 4.3$ & $33.6 \pm 2.6$ & $33.9 \pm 2.4$ & $p=0.346$ & $p=0.447$ & $p=0.306$ \\
\hline & \multicolumn{2}{|c|}{$\mathrm{d}=-0.01$} & \multicolumn{2}{|c|}{$\mathrm{d}=0.20$} & & & \\
\hline \multirow[t]{2}{*}{ Chol (mg/dl) } & $167 \pm 24$ & $168 \pm 30$ & $170 \pm 27$ & $168 \pm 26$ & $p=0.659$ & $p=0.698$ & $p=0.391$ \\
\hline & \multicolumn{2}{|c|}{$\mathrm{d}=0.04$} & \multicolumn{2}{|c|}{$d=-0.09$} & & & \\
\hline \multirow[t]{2}{*}{$\operatorname{Tg}(\mathrm{mg} / \mathrm{dl})$} & $76.4 \pm 25.8$ & $85.0 \pm 38.5$ & $80.0 \pm 34.5$ & $83.3 \pm 31.0$ & $p=0.824$ & $p=0.012^{*}$ & $p=0.254$ \\
\hline & \multicolumn{2}{|c|}{$\mathrm{d}=0.24$} & \multicolumn{2}{|c|}{$\mathrm{d}=0.11$} & & & \\
\hline \multirow[t]{2}{*}{ HDL (mg/dl) } & $66.1 \pm 13.7$ & $61.0 \pm 13.3$ & $64.0 \pm 12.2$ & $60.2 \pm 12.2$ & $p=0.371$ & $p<0.001^{*}$ & $p=0.367$ \\
\hline & \multicolumn{2}{|c|}{$\mathrm{d}=-0.44$} & \multicolumn{2}{|c|}{$d=-0.38$} & & & \\
\hline \multirow[t]{2}{*}{ LDL (mg/dl) } & $86.1 \pm 21.0$ & $101.8 \pm 101.6$ & $89.5 \pm 21.5$ & $90.7 \pm 22.4$ & $p=0.476$ & $p=0.067$ & $p=0.119$ \\
\hline & \multicolumn{2}{|c|}{$\mathrm{d}=0.16$} & \multicolumn{2}{|c|}{$\mathrm{d}=0.07$} & & & \\
\hline Glucose (mg/dl) & $\begin{array}{r}79.8 \pm 11.0 \\
d=\end{array}$ & $\begin{array}{l}76.8 \pm 10.5 \\
24\end{array}$ & $\begin{array}{r}76.81 \pm 9.2 \\
d\end{array}$ & $\begin{aligned} & 74.80 \pm 10.1 \\
= & -0.22\end{aligned}$ & $p=0.046^{*}$ & $p=0.001^{*}$ & $p=0.525$ \\
\hline
\end{tabular}

Mean \pm standard deviation; $p$ values for main effects (genotype and training) and genotype $x$ training interaction; d-effect size; BMI - body mass index; FM - fat mass percentage; FFM - fat free mass; TBW - total body water; Chol - cholesterol; Tg - triglycerides; HDL - high-density lipoprotein; LDL - low-density lipoprotein 


\section{Discussion}

Previous studies confirm a strong association between the polymorphism near MC4R gene and body weight (Haupt et al., 2009; Loos et al., 2008). However, results of the present study did not confirm this relationship of the C allele with increased body weight, BMI or other obesity-related traits. Connection between increased height and the polymorphism was also not found in our study. In fact, the small effect size (per-allele effect $=0.005$ ) of this molecular marker with human obesity implied the need of extremely large-scale data to establish some specific common variants (Kuo et al., 2011). Probably, our study had limited power to detect minor SNP effects on an increased BMI.

On the other hand, we identified a statistically significant association between the glucose level and the genotype. Participants with CC and CT genotypes had a higher glucose level during the entire study period compared with the TT genotype. Our results showed that $6.5 \%$ of individuals with the risk genotype, but no one with the TT genotype, had fasting hyperglycemia. Their glucose level ranged from 106 to $118 \mathrm{mg} / \mathrm{dl}$. Pre-diabetes, based on glycaemic variables above normal, but below diabetes thresholds, constitutes a high-risk state for diabetes with high conversion rates and there is accumulating evidence implying that damage on kidneys and nerves already exists at the pre-diabetic stage (Tabak et al., 2012). Interestingly, after the 12 week training program their glucose level was normal, and it ranged from 85 to $93 \mathrm{mg} / \mathrm{dl}$. Although, this change was not statistically significant, it shows a medically important trend, which needs further experimental investigations. Our results may suggest that SNP rs17782313 influences the regulatory region of the $M C 4 R$, which is a key regulator of energy balance and can affect food intake and energy expenditure through central melanocortin neuronal pathways (Balthasar et al., 2005). Alterations in expression of the MC4R may affect glucose utilization and insulin sensitivity (Nogueiras et al., 2007).

Chambers et al. (2008) confirmed a relationship between the glucose metabolism and SNPs localized near the MC4R gene. In this genome-wide association study, 318,237 SNPs connected with insulin resistance were analyzed. The authors described a BMI-independent association of rs12970134 with insulin resistance and related phenotypes. Our results also show that rs17782313 is connected with the glucose level, what contrasts with the findings of Haupt et al. (2009) who did not find a relationship between the SNP and glucose metabolism. Kuo et al. (2011) also did not observe a relationship between the investigated polymorphism and glucose metabolism. However, the authors identified an interaction between rs2229616 also localized near the MC4R and the insulin level. In another study, rs17782313 was associated with an increased insulin level, but not with the glucose level (Vogel et al., 2011).

In the present study, we did not observe the near MC4R C/T polymorphism x physical activity interaction. However, our results revealed that variables such as body mass, BMI, FM, FFM, $\mathrm{Tg}$, HDL, and glucose changed significantly during the 12 week training program. There were small changes in FFM $(p<0.001 ; \mathrm{d}=0.48), \operatorname{Tg}(p=$ $0.012 ; \mathrm{d}=0.24)$, HDL $(p<0.001 ; \mathrm{d}=-0.44)$, and glucose level ( $p=0.001 ; \mathrm{d}=-0.24)$. Additionally, significant changes in body mass $(p<0.001 ; \mathrm{d}=$ $0.65)$, BMI $(p<0.001 ; \mathrm{d}=-0.66)$, and FM $(p<0.001$; $\mathrm{d}=-0.80)$ were noticed. The finding that physical activity is connected with a reduction in obesityrelated traits is still a significant observation. A limitation of the lifestyle study is that the results were driven by a relatively small sample size and a short time of intervention. Thus, replication in similarly phenotyped and larger cohorts is required to fully determine the effect of the SNP on changes in body composition.

Our results may be supported by the previous study which did not show an association between the polymorphism and selected body composition measurements in 242 participants undergoing a 9-month lifestyle intervention (Haupt et al., 2009). In a study performed on 111,421 adults of European descent, Ahmad et al. (2013) analyzed 12 loci connected with obesityrelated traits and also did not reveal evidence of the polymorphism rs 17782313 x physical activity interactions, although the impact of FTO and $S E C 16 B$ genes on changes in the BMI in a group undergoing lifestyle intervention was shown. In contrast to our study, Li et al. (2010) genotyped 12 SNPs in obesity-susceptibility loci including rs17782313 in a group of 20,430 European subjects, and showed that the genetic 
predisposition to an increased BMI and obesity was attenuated by a physically active lifestyle.

The study has several limitations that should be mentioned. The failure to detect a gene $x$ physical activity interaction in our study may reflect the influence of population-specific characteristics such as high overall physical activity levels and relatively low body mass in the studied population, a small sample size or the effect of age (Li et al. 2010). In addition, obesity is a polygenic trait, as a result the genetic marker analysed independently is likely to make only a limited contribution to the obesity phenotype: it seems more likely that such status depends on the simultaneous presence of multiple such variants.

In summary, we identified a statistically significant relationship between the glucose level and genotype, what is an important observation from a medical point of view. Participants with CC and CT genotypes had a higher glucose level during the entire study period compared with the TT genotype. However, we did not confirm the effect of the near $M C 4 R \quad C / T$ polymorphism (rs17782313) on the higher BMI or other obesityrelated traits. Although selected body mass and body composition variables, as well as obesity- related metabolic variables changed significantly during the 12 week training program, we found no evidence of an interaction between the investigated polymorphism and physical activity in chosen variables. However, we would like to point out that promoting physical activity, particularly in those subjects who are genetically predisposed to obesity, is an important step towards controlling the currently increasing obesity epidemic. More experimental studies are needed to explain the association between the glucose level and genotype, as well as to establish the gene $x$ physical activity interaction. Research conducted on amateurs allows for better understanding of the genetic basis of post-effort adaptation mechanisms. Yet, these results constitute an excellent source of information, which after thorough analysis and replication can be used for the needs of competitive sports. In the future, the results described in this article can be used for the purpose of modeling the energy management and weight control in professional athletes representing mostly endurance sport disciplines.

\section{Acknowledgements}

The study was supported by the National Science Centre (grant no. 2012/07/B/NZ7/01155).

\section{References}

Ahmad S, Rukh G, Varga TV, Ali A, Kurbasic A, Shungin D, Ericson U, Koivula RW, Chu AY, Rose LM, Ganna A, Qi Q, Stančáková A, Sandholt CH, Elks CE, Curhan G, Jensen MK, Tamimi RM, Allin KH, Jørgensen T, Brage S, Langenberg C, Aadahl M, Grarup N, Linneberg A, Paré G. Gene × physical activity interactions in obesity: combined analysis of 111,421 individuals of European ancestry. PLoS Genet, 2013; 9(7): e1003607

Balthasar N, Dalgaard LT, Lee CE, Yu J, Funahashi H, Williams T, Ferreira M, Tang V, McGovern RA, Kenny CD, Christiansen LM, Edelstein E, Choi B, Boss O, Aschkenasi C, Zhang CY, Mountjoy K, Kishi T, Elmquist JK, Lowell BB. Divergence of melanocortin pathways in the control of food intake and energy expenditure. Cell, 2005; 123(3): 493-505

Chambers JC, Elliott P, Zabaneh D, Zhang W, Li Y, Froguel P, Balding D, Scott J, Kooner JS. Common genetic variation near MC4R is associated with waist circumference and insulin resistance. Nat Genet, 2008; 40(6): 716-718

Evans DS, Calton MA, Kim MJ, Kwok PY, Miljkovic I, Harris T, Koster A, Liu Y, Tranah GJ, Ahituv N, Hsueh WC, Vaisse C. Genetic association study of adiposity and melanocortin-4 receptor (MC4R) common variants: replication and functional characterization of non-coding regions. PLoS One, 2014; 9(5): e96805

Franks PW. Gene × environment interactions in type 2 diabetes. Curr Diab Rep, 2011; 11(6): 552-561

Gantz I, Miwa H, Konda Y, Shimoto Y, Tashiro T, Watson SJ, DelValle J, Yamada T. Molecular cloning, expression, and gene localization of a fourth melanocortin receptor. J Biol Chem, 1993; 268(20): 15174- 
15179

Haupt A, Thamer C, Heni M, Tschritter O, Machann J, Schick F, Machicao F, Häring HU, Staiger H, Fritsche A. Impact of variation near MC4R on whole-body fat distribution, liver fat, and weight loss. Obesity (Silver Spring), 2009; 17(10): 1942-1945

Hebebrand J, Volckmar AL, Knoll N, Hinney A. Chipping away the 'missing heritability': GIANT steps forward in the molecular elucidation of obesity - but still lots to go. Obes Facts, 2010; 3(5): 294-303

Hopkins WG, Marshall SW, Batterham AM, Hanin J. Progressive statistics for studies in sports medicine and exercise science. Med Sci Sports Exerc, 2009; 41(1): 3-13

Kostrzewa-Nowak D, Nowak R, Jastrzębski Z, Zarębska A, Bichowska M, Drobnik-Kozakiewicz I, Radzimiński Ł, Leońska-Duniec A, Ficek K, Cięszczyk P. Effect of 12-week-long aerobic training programme on body composition, aerobic capacity, complete blood count and blood lipid profile among young women. Biochemia Medica, 2015; 25(1): 103-113

Kuo PH, Kao CF, Chen PY, Chen CH, Tsai YS, Lu ML, Huang MC. Polymorphisms of INSIG2, MC4R, and LEP are associated with obesity- and metabolic-related traits in schizophrenic patients. J Clin Psychopharmacol, 2011; 31(6): 705-711

Li S, Zhao JH, Luan J, Ekelund U, Luben RN, Khaw KT, Wareham NJ, Loos RJ. Physical activity attenuates the genetic predisposition to obesity in 20,000 men and women from EPIC-Norfolk prospective population study. PLoS Med, 2010; 7(8): e1000332

Loos RJ. Genetic determinants of common obesity and their value in prediction. Best Pract Res Clin Endocrinol Metab, 2012; 26(2): 211-226

Loos RJ, Lindgren CM, Li S, Wheeler E, Zhao JH, Prokopenko I, Inouye M, Freathy RM, Attwood AP, Beckmann JS, Berndt SI; Prostate, Lung, Colorectal, and Ovarian (PLCO) Cancer Screening Trial, Jacobs KB, Chanock SJ, Hayes RB, Bergmann S, Bennett AJ, Bingham SA, Bochud M, Brown M, Cauchi S, Connell JM, Cooper C, Smith GD, Day I, Dina C, De S, Dermitzakis ET, Doney AS, Elliott KS, Elliott P, Evans DM, Sadaf Farooqi I, Froguel P, Ghori J, Groves CJ, Gwilliam R, Hadley D, Hall AS, Hattersley AT, Hebebrand J, Heid IM; KORA, Lamina C, Gieger C, Illig T, Meitinger T, Wichmann HE, Herrera B, Hinney A, Hunt SE, Jarvelin MR, Johnson T, Jolley JD, Karpe F, Keniry A, Khaw KT, Luben RN, Mangino M, Marchini J, McArdle WL, McGinnis R, Meyre D, Munroe PB, Morris AD, Ness AR, Neville MJ, Nica AC, Ong KK, O'Rahilly S, Owen KR, Palmer CN, Papadakis K, Potter S, Pouta A, Qi L; Nurses' Health Study, Randall JC, Rayner NW, Ring SM, Sandhu MS, Scherag A, Sims MA, Song K, Soranzo N, Speliotes EK; Diabetes Genetics Initiative, Syddall HE, Teichmann SA, Timpson NJ, Tobias JH, Uda M; SardiNIA Study, Vogel CI, Wallace C, Waterworth DM, Weedon MN; Wellcome Trust Case Control Consortium, Willer CJ; FUSION, Wraight, Yuan X, Zeggini E, Hirschhorn JN, Strachan DP, Ouwehand WH, Caulfield MJ, Samani NJ, Frayling TM, Vollenweider P, Waeber G, Mooser V, Deloukas P, McCarthy MI, Wareham NJ, Barroso I, Jacobs KB, Chanock SJ, Hayes RB, Lamina C, Gieger C, Illig T, Meitinger T, Wichmann HE, Kraft P, Hankinson SE, Hunter DJ, Hu FB, Lyon HN, Voight BF, Ridderstrale M, Groop L, Scheet P, Sanna S, Abecasis GR, Albai G, Nagaraja R, Schlessinger D, Jackson AU, Tuomilehto J, Collins FS, Boehnke M, Mohlke KL. Common variants near MC4R are associated with fat mass, weight and risk of obesity. Nat Genet, 2008; 40(6): 768-775

Lu D, Willard D, Patel IR, Kadwell S, Overton L, Kost T, Luther M, Chen W, Woychik RP, Wilkison WO, et al. Agouti protein is an antagonist of the melanocyte-stimulating-hormone receptor. Nature, 1994; 371(6500): 799-802

Meyre D, Delplanque J, Chèvre JC, Lecoeur C, Lobbens S, Gallina S, Durand E, Vatin V, Degraeve F, Proença C, Gaget S, Körner A, Kovacs P, Kiess W, Tichet J, Marre M, Hartikainen AL, Horber F, Potoczna N, Hercberg S, Levy-Marchal C, Pattou F, Heude B, Tauber M, McCarthy MI, Blakemore AI, Montpetit A, Polychronakos C, Weill J, Coin LJ, Asher J, Elliott P, Järvelin MR, Visvikis-Siest S, Balkau B, Sladek R, Balding D, Walley A, Dina C, Froguel P. Genome-wide association study for early-onset and morbid adult obesity identifies three new risk loci in European populations. Nat Genet, 2009; 41(2): 157-159 
Mountjoy KG, Mortrud MT, Low MJ, Simerly RB, Cone RD. Localization of the melanocortin-4 receptor (MC4-R) in neuroendocrine and autonomic control circuits in the brain. Mol Endocrinol, 1994; 8(10): 1298-1308

Nogueiras R, Wiedmer P, Perez-Tilve D, Veyrat-Durebex C, Keogh JM, Sutton GM, Pfluger PT, Castaneda TR, Neschen S, Hofmann SM, Howles PN, Morgan DA, Benoit SC, Szanto I, Schrott B, Schürmann A, Joost HG, Hammond C, Hui DY, Woods SC, Rahmouni K, Butler AA, Farooqi IS, O'Rahilly S, RohnerJeanrenaud F, Tschöp MH. The central melanocortin system directly controls peripheral lipid metabolism. J Clin Invest, 2007; 117(11): 3475-3488

Qi L, Kraft P, Hunter DJ, Hu FB. The common obesity variant near MC4R gene is associated with higher intakes of total energy and dietary fat, weight change and diabetes risk in women. Hum Mol Genet, 2008; 17(22): 3502-3408

Rankinen T, Bouchard C. Gene-Physical activity interactions: overview of human studies. Obesity (Silver Spring), 2008; 16: 47-50

Scherag A, Jarick I, Grothe J, Biebermann H, Scherag S, Volckmar AL, Vogel CI, Greene B, Hebebrand J, Hinney A. Investigation of a genome wide association signal for obesity: synthetic association and haplotype analyses at the melanocortin 4 receptor gene locus. PLoS One, 2010; 5(11): e13967

Schwartz MW, Woods SC, Porte D Jr, Seeley RJ, Baskin DG. Central nervous system control of food intake. Nature, 2000; 404(6778): 661-671

Tabák AG, Herder C, Rathmann W, Brunner EJ, Kivimäki M. Prediabetes: a high-risk state for diabetes development. Lancet, 2012; 379(9833): 2279-2290

Thorleifsson G, Walters GB, Gudbjartsson DF, Steinthorsdottir V, Sulem P, Helgadottir A, Styrkarsdottir U, Gretarsdottir S, Thorlacius S, Jonsdottir I, Jonsdottir T, Olafsdottir EJ, Olafsdottir GH, Jonsson T, Jonsson F, Borch-Johnsen K, Hansen T, Andersen G, Jorgensen T, Lauritzen T, Aben KK, Verbeek AL, Roeleveld N, Kampman E, Yanek LR, Becker LC, Tryggvadottir L, Rafnar T, Becker DM, Gulcher J, Kiemeney LA, Pedersen O, Kong A, Thorsteinsdottir U, Stefansson K. Genome-wide association yields new sequence variants at seven loci that associate with measures of obesity. Nat Genet, 2009; 41(1): 1824

Vogel CI, Boes T, Reinehr T, Roth CL, Scherag S, Scherag A, Hebebrand J, Hinney A. Common variants near MC4R: exploring gender effects in overweight and obese children and adolescents participating in a lifestyle intervention. Obes Facts, 2011; 4(1): 67-75

Xi B, Chandak GR, Shen Y, Wang Q, Zhou D. Association between common polymorphism near the MC4R gene and obesity risk: a systematic review and meta-analysis. PLoS One, 2012; 7(9): e45731

\section{Corresponding author:}

\section{Agata Leońska-Duniec}

Faculty of Physical Culture and Health Promotion, University of Szczecin

Al. Piastów 40B, blok 6

71-065 Szczecin, Poland

Phone: +48 (91) 4442784

Fax: +48 (91) 4442734

E-mail: leonska.duniec@gmail.com 